\title{
Vocational Education in Higher Secondary Schools
}

\author{
Shireesh Pal Singh Ph.D. (Ed.)
}

Centre for Education, School of Informative and Communicative Sciences, Central University of Punjab, Bathinda, India Email: shireeshsingh1982@gmail.com

Sumita Grover

M.Ed. Scholar, IGNOU Regional Centre Bhopal, India

Jubilee Padmanabhan Ph.D. (Ed.)

Assistant Professor, Centre for Education, Central University of Punjab, Bathinda, India

Sarita Chaudhary, Ph.D (Pur.)

Assistant Professor, Shree Satya Sai B.Ed College, Karaiwala, Malout, Punjab. India

\section{Doi:10.5901/mjss.2015.v6n5p455}

\begin{abstract}
The competent and trained manpower would be contributing significantly to the industrial development of the nation by establishing small industries. Rapid changes in technology, expansion of market, industrial policies of the Government, coming in of more multinationals due to liberalization have revolutionized the aspect of Vocational Education at present the object of vocational education can be achieved by adequate school management. When we talk about objectives of vocational education, we mean to prepare students for self-employment and develop them as skilled manpower. Vocationalisation of Secondary Education is important from the point of view of the economic development of the developing country like ours. Such an education will inculcate the habit of hard work and dignity of labor among the students. This programme will help to solve the problem of unemployment and prepare the way for self-employment. The Present paper is the outcomes of the study of vocational education in higher secondary schools of Bhopal division Bhopal Division comprises of Bhopal, Raisen, Vidhisha, Sehore and Rajgarh districts. Vocational Courses were introduced for the first time in 1988. According to the figures of 19961997 Vocational Courses introduced in thirty-one schools of Bhopal division. For study ten schools where vocational courses are running, selected by investigators randomly. Data collected with the help of various tools like questionnaire and interview schedules. Results of the study reveal that there is a need to strengthen vocational education in the region.
\end{abstract}

Keywords: Vocational Education, Secondary Schools, Bhopal District

\section{Introduction}

India is one of the oldest civilizations with a rich creative culture heritage. In the present age of Information Technology, it has adequate human and natural resources and infrastructure to rising. Two decades ago Vocational Educational programme (VEP) was institutionalized, and it was envisaged that there would be a diversion of about $25 \%$ students from general education to Vocational Education. The competent and trained manpower would be contributing significantly to the industrial development of the nation by establishing small industries. Rapid changes in technology, expansion of the market, industrial policies of the Government, coming in of more multinationals due to liberalization have revolutionized the aspect of Vocational Education at present.

The term "Vocational Education" in its broadest sense (as used by the National Working Group on Vocationalisation of Education, under the chairmanship of Dr. V.C.Kulandaiswamy ,1985) covers education and skills development all levels from post-primary to tertiary education both from formal and non-formal programmes. Vocational education is multi-dimensional and it has several levels. Vocational education may be seen as the totality of experiences through which one learns about and prepares to engage in work as a part of one's way of living (means of livelihood being a part of it). It encompasses all formal as well as informal instruction for students at the secondary or postsecondary level, and the working or displaced personnel; and prepares them by imparting and acquainting with the necessary skills, understandings, attitudes and abilities for entry into and advancement in a particular occupation or a cluster of related occupations. The above-mentioned facts show that the aims of vocationalisation of education are directly linked with the progress of our nation. An effective vocationalisation of school education is very badly needed in 
India today.

Vocational subjects are desirable on general education grounds, but they should not distract from efforts to improve the quality of core subjects. Vocationalization is costly, most variants of vocational education are more expensive per student per class period than general education subjects, primarily because of small classes and the greater cost of facilities, equipment, and consumables. Unit costs of Vocational Education are roughly 60 percent higher than that of general secondary education. As Enrolment of some types of vocational courses is often strongly gendered biased. Many skills taught are culturally identified with one gender only; for example, domestic science and secretarial skill with girls, and industrial art skills with boys so it is hard to implement vocationalization effectively (Johansson \& Adams, 2004).

The Father of our Nation Mahatma Gandhi also advocated for Vocational Education. The most comprehensive recommendations towards vocationalisation of Higher-Secondary Education came from the recommendation of the Education Commission (1964-66). It presents a blueprint for the complete transformation of the education system in the country. In pursuance of the policy, the national efforts were guided by a centrally sponsored scheme (CSS) which came into operation with effect from February 1988. The schemes provided building up of infrastructure facilities, development of management system, and the establishment of linkages for the implementation of a collaborative model of Vocational Education in the country. The scheme is funded by the Central Government. The Vocational Education programme (VEP) is implemented through the State and Union Territory governments. Establishing a close relation between the education and employment, training persons for self-employment in Agriculture, Small Scale Industries and Service Sector were some of the objectives of this Programme.

The objectives of vocational education can be achieved by adequate school management. When we talk about objectives of vocational education, we mean to prepare students for self-employment and develop them as skilled manpower. Management of vocational education consists of managing two elements- Human and physical. Human elements consist of staffs, committees, and other Personnel; while the physical elements comprises of school building, furniture, Library, other educational accessories and equipments. Besides these two elements, school routine, curriculum and timetable are also a matter of particular attention for management. It is the responsibility of school management to arrange better physical and human resources for proper training of students. The total concept of organization should be so implemented that in the school the Principal, the teachers, the students, the staff members as well as guardians, the members of local community and education authorities may function in a spirit of a team. The success of vocation education would depend on the coordinated function of all these elements.

Bhopal district comprises of two tehsils -Hujur and Berasaia. Hujur tehsil covers urban area whereas Berasaia covers rural area mostly. There is a difference in the nature of courses introduced in the rural and urban area of this district. The vocational courses have been introduced according to the need of area. In the urban area the courses like Steno-Typing, Scooter and Motor-Cycle repairing, Radio and T.V. repairing, X-ray technician, Banking Assistant, Garment making, Food and Vegetable Preservation etc. have been introduced. In the rural area courses like Dairy Farming and Farm, Mechanics has been introduced. There are thirteen schools in the district which are conducting various vocational courses.

\subsection{Challenges to Vocational Education and Training}

The combined impact of the challenges in the Vocational Education and Training (VET) sector is causing increased pressure on the work of teacher and trainers. The factors, such as government policies, changing labour market, demand and supply of skills, competency-based education and training, etc., influence the delivery of TET.

\subsection{Government Policies}

The National Policy on Skill Development 2009 of Government of India provides directions and strategies for implementation of effective skill development programmes. According to the policy, skill development has many challenges. The major challenges that the VET will face are as follows:

- Increase capacity and capability of the existing skill development system to ensure equitable access to all.

- Promote life-long learning.

- Maintaining quality and relevance, according to the changing labour market requirements.

- Create effective convergence between general and vocational education.

- Capacity building of institutions for planning, quality assurance and involvement of stakeholders.

- Create institutional mechanism for research, examination, certification, affiliation and accreditation. 
- Increase participation of stakeholders; mobilize adequate investment for financing skill development, and attaining sustainability by strengthening physical and intellectual resources.

The Government is now promoting coordinated action for skill development with the involvement of key stakeholders - Central Ministries, State Governments, National Council on Skill Development (NCSD), National Skill Development Coordination Board (NSDCB), National Skill Development Corporation (NSDC) and Industry represented by the Sector Skill Councils (SSCs). The Ministry of Human Resource Development (MHRD), Government of India has developed a National Vocational Education Qualifications Framework (NVEQF) (Executive Order F. No. I-4/20ll-VE, dated $3^{\text {rd }}$ September, 2012 of MHRD). NVEQF is a descriptive framework that organizes qualifications according to a series of levels of knowledge along with skills. These levels are defined in terms of learning outcomes i.e., the competencies which the learners must possess regardless of whether they were acquired through formal, non-formal or informal education and training. Qualifications are made up of occupational standards for specific areas of learning units. National occupation standards are being laid down by the Sector Skill Councils (SSCs) for different jobs in their respective sectors. The PSS Central Institute of Vocational Education (PSSCIVE), Bhopal is the nodal agency for research and development, including development of competency based curriculum and teaching-learning material and organization of orientation and training programmes for key functionaries and teachers.

The Government has set a target for providing skills to 500 million people by 2022, and skilling people are among the most important priorities of the Government in the $12^{\text {th }}$ Five Year Plan. The radical changes in the skill development programmes will warrant specialized training, retraining and skills development of the teachers and trainers. The teachers and trainers will have to prepare themselves to meet the above mentioned challenges keeping in view the policy directions on skill development.

\subsection{Labour Market Demands}

Vocational Teachers should prepare students not only for specific skills, as many of them become obsolete on-the-job, but also for transferable skills i.e., the capacity to learn and apply skills under different work environment. They have to prepare their students for the new realities of the workplace and labour market by ensuring that the skills imparted to them are attuned to the labour market requirements. The vocational teachers and trainers will face a challenge to prepare people for the changing skills demand and to match the demand and supply of skill, based on the labour market information system.

\subsection{Learners' Needs}

Learners' characteristics, which include study habits, learning style, age, sex, motivation, moral values, and socioemotional cognitive and character development affects the extent of involvement of the learner in the process of learning. These characteristics are important in the relationship of classroom processes/behaviour and school achievement (Huitt, 1995). Learners have preferences about how they like to learn, which is called their learning style. Vocational teachers and trainers have to address the learner's needs in the classroom and workplace.

\subsection{Competency-based Education and Training}

Competency Based Education and Training (CBET) is about assisting individuals to acquire skills and knowledge so that they are able to perform a task to a specified standard under certain conditions. It is a structured approach to training and assessment that is directed towards achieving specific learning outcomes. Vocational teachers and trainers will have to accept the challenge of delivering competency-based education and training and conducting assessment procedures on well-defined learning objectives to prepare their students to industry-set skill standards and to meet the new and emerging challenges in the world of work.

\subsection{Technology-enabled Work}

Radical technological developments and innovations at work have transformed the skill requirements from traditional skills to modern technology-oriented skills and computer-mediated skills. Use of technology has not only created new opportunities and creation of innovative design and structures, but it also resulted in enhanced productivity and prosperity. The major challenge that the vocational teachers and trainers are facing in the 21 century is to prepare human resource which is trained in performing technology-enabled work. Teachers' will, therefore, have to prepare themselves 
for using technology and computers.

\section{Objectives of the Study}

Vocationalisation of Secondary education is important from the point of view of the economic development of the developing country like ours. Such an education will inculcate the habit of hard work and dignity of labor among the students. This programme will help to solve the problem of unemployment and prepare the way for self-employment. Considering this important aspect of Vocational Education, the following objectives included in the focus of present study, related to Vocational Higher Secondary schools of Bhopal district of Madhya Pradesh state in India.

- To study the effectiveness of the Vocational Education Programme

- To study the present status of Vocational Education.

- To find out the problem in way of effective implementation of Vocational Education/Schemes

- To invite the suggestions for quality enhancement of Vocational Education.

- To study the problems of management of Vocational Education.

- To study the attitude of students towards Vocational Education.

- To study the reaction of guardians.

- To study the methods of teaching adopted to teach the students of Vocational Education.

- To study the reaction of Ex-students of Vocational Education.

\section{Method of Study}

The study was carried out as a 'descriptive research'. Unlike experimental research focusing on exploring cause \& effect relationship, descriptive research is concerned with studying what exists. It interprets and explains the existence of educational phenomena. This method is concerned with surveying describing and investigating the existing phenomena, conditions and relationships.

The present study was in the nature of a survey and was conducted in 10 Vocational Higher Secondary Schools of Bhopal District. The 100 Students of both $11^{\text {th }}$ and $12^{\text {th }}$ class were randomly selected for this study. The other components of the sample are: 100 Students, 10 Principals, 30 Ex-Students, 20 Lectures / Teachers, 30 Guardians to make this study objective based and to arrive at a conclusion, the view and valuable suggestion of the Joint Director, Public Instruction Bhopal division, Bhopal and the Dy. Director of Education, Bhopal have also been included in the present study.

\section{Tools and Techniques Used in the Study}

The Questionnaire has been used to collect data from students, Ex-students, Principals and Teachers of Vocational Higher Secondary Schools of Bhopal district. The Questionnaire was made to collect the information on different aspects of vocational education like entry level of students in vocational education, guardian's views about future of vocation education and availability of vocational institutions in Bhopal region. . Attitude scale has been used to study the reactions of the pupils. Interview schedule have been used to collect data from the Principals, Guardians and senior Officers of Education district.

Diagrams and graphs have been used to represent statistical results related to the questionnaire. Descriptive statistics like mean, median, mode, standard deviation and coefficient of skewness were employed to know the nature of data related to attitude scale.

\section{Data Collection}

The tools mentioned above were used for the collection of data. All the instruments were personally used by the investigator. In the present study questionnaire, interview, schedules and the attitude scale were used. The data was collected in the following manner from different persons.

- The Students: The questionnaire for the students was given to them. After the rest of ten minutes the attitude scale was distributed to the same subjects.

- The Lectures / Teachers: The questionnaire for the Lectures and teachers were given to them

- Ex-Students: They were also given questionnaire. 
- The Guardians: Information's from the guardians were collected with the help of interview schedule.

- The Joint Director / The Dy Director / The Principal: Important information related to vocationalisation of Higher Secondary Schools in Bhopal District was collected from them with the help of interview schedules. Other relevant information related to Vocational Education in the Bhopal District + 2 level were obtained from office of the DPI, Bhopal, Office of the Joint Director, Public Instruction, Bhopal Division, Bhopal Office of the Dy Director of Education, Bhopal and different Vocational Higher Secondary Schools of the district.

\section{Analysis and Interpretation of Data}

Data collected from the test and experiments often have little meaning and significance until they have been rearranged to classify in a systematic manner. Here the data obtained from different sources have been analysed to find out the effectiveness of implementation of vocational courses in 10 Higher Secondary Schools in Bhopal District as follows.

\subsection{Availability of Vocational Schools in the District}

On the basis of information received from the Office of the Dy. Director, Education Bhopal, there are 31 Government Higher Secondary Schools, in Bhopal district. Only 13 Higher Secondary Schools are conducting Vocational Courses. Out of 13 Vocational Higher Secondary Schools, one is rural area, and the other twelve schools are situated in the urban area.

Table 1. Vocational schools in Bhopal district

\begin{tabular}{|c|c|c|c|c|}
\hline S.No & $\begin{array}{c}\text { Vocational Higher Secondary } \\
\text { Schools Urban }\end{array}$ & $\begin{array}{c}\text { Vocational Higher Secondary } \\
\text { Schools Rural }\end{array}$ & $\begin{array}{c}\text { Non Vocational Higher } \\
\text { Secondary Schools }\end{array}$ & $\begin{array}{c}\text { Total Higher Secondary } \\
\text { Schools }\end{array}$ \\
\hline 1. & 12 & 01 & 18 & 31 \\
\hline
\end{tabular}

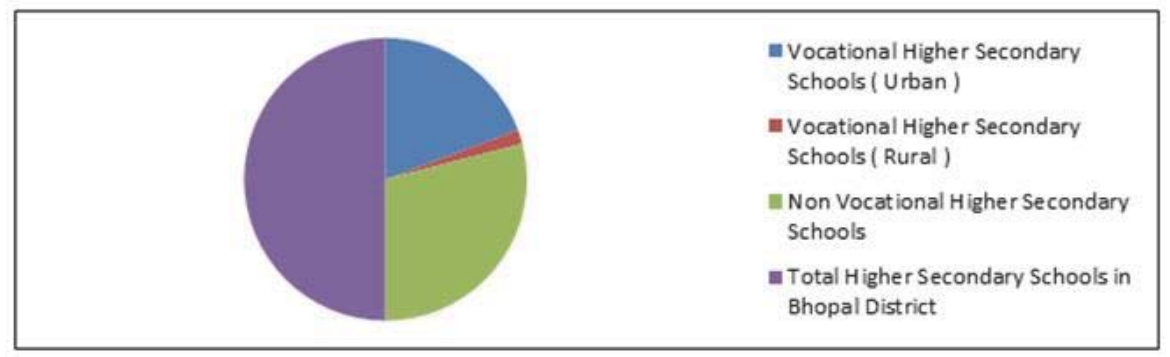

Figure 1. Percentage of Vocational and Non Vocational Higher Secondary Schools in Bhopal District

\subsubsection{Interpretation and Findings}

Considering the multi-dimensional objective of the vocational education, there is a need to introduce vocational courses in higher secondary schools of the district. We know that Bhopal district has high social and educational status. It would be maintained in the field of vocational education too. There is an urgent requirement of skilled manpower in the rural area. The number of vocational schools in rural should be according to the need of the people. There are 31 Govt Higher Secondary Schools in Bhopal District, and only 13 Higher Secondary Schools are conducting vocational courses. There is only one vocational Higher Secondary School in Bhopal District ,which is situated in the rural area. There are more than one hundred Non-Government Higher Secondary Schools in Bhopal District. Not even a single Non-Government Higher Secondary Schools in conducting vocational courses. 


\subsection{Guardians View about the Future of their Children after Finishing Vocational Courses}

Table 2. Guardians View about the future in Vocational Education of their children

\begin{tabular}{clccc}
\hline S.No. & Nature of Occupation Desired By Guardians & No. of Guardians & Total & $\%$ \\
\hline 1 & Service & 6 & 6 & $20 \%$ \\
2 & Service \& Self-employment & 22 & 22 & $73.33 \%$ \\
3 & Technical knowledge & 02 & 02 & $6.66 \%$
\end{tabular}

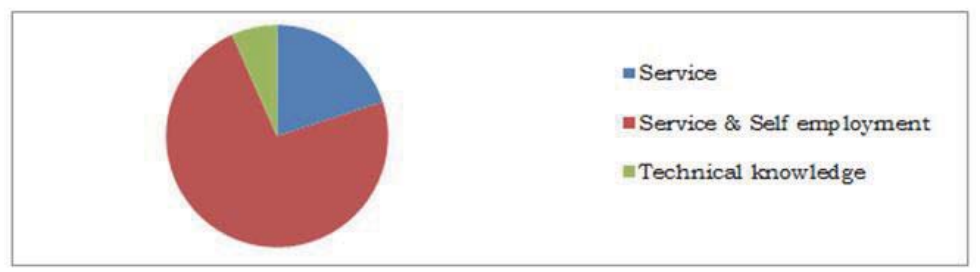

Figure 2. Guardians View about the future Vocational Education of their children

As evident most of the guardians want their children to be either go in for service or be self-employed once they finish their vocational education course. Some of them, however would like their children to have technical knowledge once they have completed their course.

\subsection{Present Status of Working Ex-Students}

Tabel 3. Present status of working Ex- Students.

\begin{tabular}{|c|l|c|c|}
\hline S.No. & Nature of Work & No of Ex-Students & $\%$ \\
\hline 1. & Higher Education & 20 & 66.66 \\
\hline 2. & Employed in public or private sector & 07 & 23.33 \\
\hline 3. & Self-employed & 03 & 10 \\
\hline
\end{tabular}

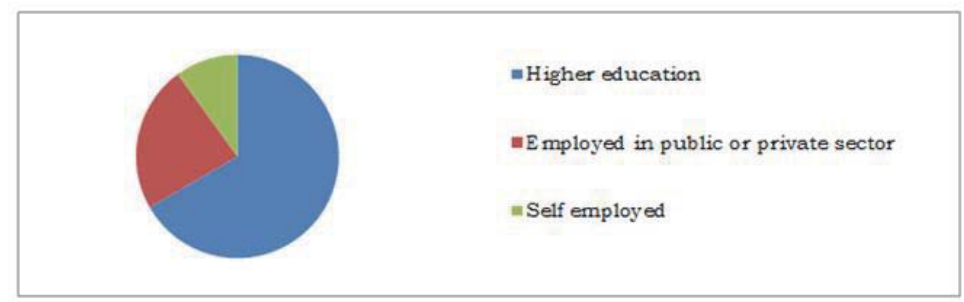

Figure 3. Present status of working Ex Students.

The success of ex-students is directly related to the success of a vocational programme in the Bhopal district. There is an urgent need to make vocational education more objective based. Most of the ex-students have opted for higher education. Either they wanted to or because they did not get a chance to be a part of the corporate sector.

\subsection{Entry Educational Level of Vocational Students in Bhopal District}

Students enter in Vocational Courses at +2 levels after passing High School examination. The information's collected through questionnaire indicate that three (3) students got First Division, 31 got second, 60 got third division and other passed in supplementary examination of Board The following table clearly indicates their position in this regard. 
Table 4. Entry educational level of the students of Vocational courses in Bhopal district

\begin{tabular}{|c|l|c|c|}
\hline Sl. No. & Division & No. of Students & $\%$ \\
\hline 1 & First & 03 & $03 \%$ \\
\hline 2 & Second & 31 & $31 \%$ \\
\hline 3 & Third & 60 & $60 \%$ \\
\hline 4 & Passed in Supplementary Examination & 06 & $06 \%$ \\
\hline
\end{tabular}

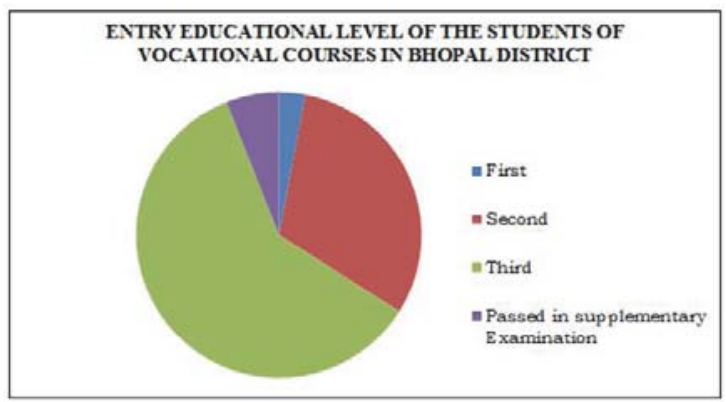

\subsubsection{Interpretation}

The educational entry level aspect of students clearly indicates that most of the students have yet not been attracted towards Vocational Courses Whatever the reason may be, Vocational Courses need to be popularized. It should attract the mass so that the objectives of the implementation of Vocational Courses can be achieved in Bhopal district. Entry education level of the students in Vocational Course of Bhopal district clearly indicated that $60 \%$ students got the third division, $31 \%$ second, first and $6 \%$ passed in a supplementary examination of High School.

\subsection{View of Students about the Present Problems of their Schools}

On this aspect $22 \%$ students say that there are no problems in their school, $25 \%$ students tell about lack of library and text books, $25 \%$ students say about lack of practical equipment's $5 \%$ students say about lack of teachers and others tell about miscellaneous problems. Their views about the issues related to their school have been given in the following table.

Table 5. Views of the students about the problems related to their schools

\begin{tabular}{|c|l|c|c|}
\hline SI. No & Problem Related Aspect & No. of Students who feel such problem & $\%$ \\
\hline 1 & Lack of library and textbook facilities & 25 & $25 \%$ \\
\hline 2 & Lack of practical equipments & 25 & $25 \%$ \\
\hline 3 & Lack of teachers & 5 & $5 \%$ \\
\hline 4 & Miscellaneous Problems & 23 & $23 \%$ \\
\hline 5 & No problem & 22 & $22 \%$ \\
\hline
\end{tabular}

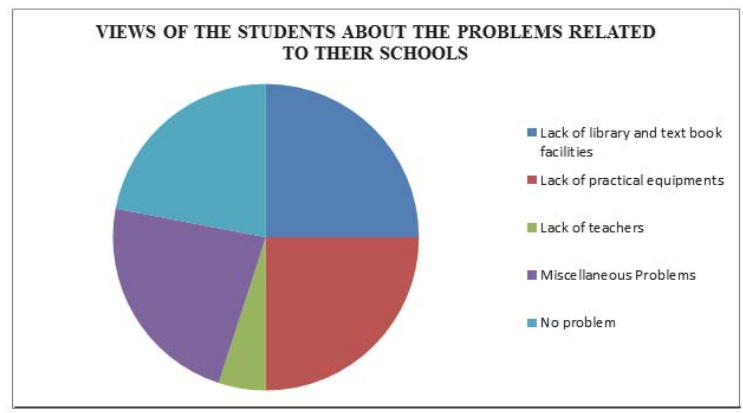




\subsubsection{Interpretation}

The above-mentioned facts clearly indicate that there should be a better library and laboratory facilities in vocational higher secondary schools of Bhopal District. The studies of Dr Sacheti [1990] in Rajasthan and Dr Gupta [1991] in Karnataka convey the same facts. Library and laboratory facilities are imperative in the successful implementation of vocational education. There is a lack of library and laboratory facilities in vocational higher secondary schools of Bhopal district.

\subsection{Suggestions of the Teachers for the Successful Implementation of Vocational Programme in Bhopal District}

Table 6. Teacher's suggestions for the successful implementation of vocational programme in Bhopal district

\begin{tabular}{|c|l|c|c|}
\hline S.No & Suggestions & No of Teachers & $\%$ \\
\hline 1. & Better Libraries and Institutional Material & 12 & 60 \\
\hline 2. & Better Laboratories \& Equipment Facilities & 06 & 30 \\
\hline 3. & Both laboratory and library facilities & 03 & 10 \\
\hline
\end{tabular}

The teachers have proposed very practical and rational suggestions to implement correctely the vocational programme. Though most of us would want both library and laboratory facilities, most of the teachers have given priority to library services keeping in mind the importance of the library in the context of education.

\subsection{Occupational Level of Father / Guardians of Students in Vocational Courses of Bhopal District}

Students are very crucial in any educational study. The success of any educational programme is directly related to the pupils. It becomes necessary for the investigators to take into account all aspect related to students. Here the occupational level of guardians of the students studying in vocational courses of Bhopal District have been given below.

Table 7. Occupational level of guardians of students in vocational courses of Bhopal district

\begin{tabular}{|c|c|c|c|}
\hline SI. no. & Nature of Occupation & No of fathers/Guardian & Percentage \\
\hline 1. & Service & 70 & 70 \\
\hline 2. & Business & 10 & 10 \\
\hline 3. & Agriculture & 11 & 11 \\
\hline 4. & Others & 9 & 9 \\
\hline
\end{tabular}

\begin{tabular}{|ll|}
\hline & Service \\
& $=$ Business \\
& $=$ Agriculture \\
& \\
\hline
\end{tabular}

It has been found that most of the students included to this study belong in middle and lower middle-level social status. They want to settle early in life and are inclined to join Vocational Courses if these predominantly practice oriented such that they may obtain a job at the end of the course.

\subsection{Difficulties of the Students in Examination}

The information received from the students about the use of evaluation procedure by the teacher clearly indicates that $77 \%$ teachers use verbal evaluation whereas $23 \%$ teachers use written tests at times. They have also told about their difficulties in the examination. 
Table 8. Difficulties of the students in examination

\begin{tabular}{|c|l|c|c|c|}
\hline S.No. & Nature of Difficulty & No. of Students & Total & $\%$ \\
\hline 1 & In understanding vocational terms & 20 & 20 & $20 \%$ \\
\hline 2 & In making figures & 15 & 15 & $15 \%$ \\
\hline 3 & In describing with diagram & 18 & 18 & $18 \%$ \\
\hline 4 & In writing the basic aspect of vocational rules & 25 & 25 & $25 \%$ \\
\hline 5 & In solving the problems in lack of basis knowledge & 22 & 22 & $22 \%$ \\
\hline
\end{tabular}

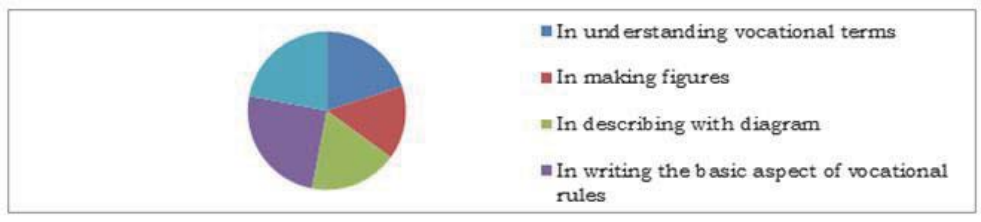

The cause of their difficulties can be easily understood $32 \%$ students say the lecture method is used by the teachers. The nature of vocational education is technical. It should be taught in technical courses Practical should be given more importance.

\subsection{Suggestions of the Students}

Table 9. Suggestions of the students

\begin{tabular}{llcl}
\hline S.No. & \multicolumn{1}{c}{ Suggestion } & $\%$ \\
\hline & & 28 & 28 \\
2 & Vocational Courses should be popularized & 08 & 8 \\
3 & Better facilities for Higher Education & 10 & 10 \\
4 & Loan facilities for Self-employment & 10 & 10 \\
5 & Service facilities & 20 & 20 \\
6 & Better physical and Human Resources & 02 & 02 \\
7 & These courses should begin from $9^{4}$ and 10th & 02 & 02 \\
8 & Diploma Certificate should be given & 01 & 01 \\
9 & Use of Local Language in Vocational Courses & 19 & 19 \\
\hline
\end{tabular}

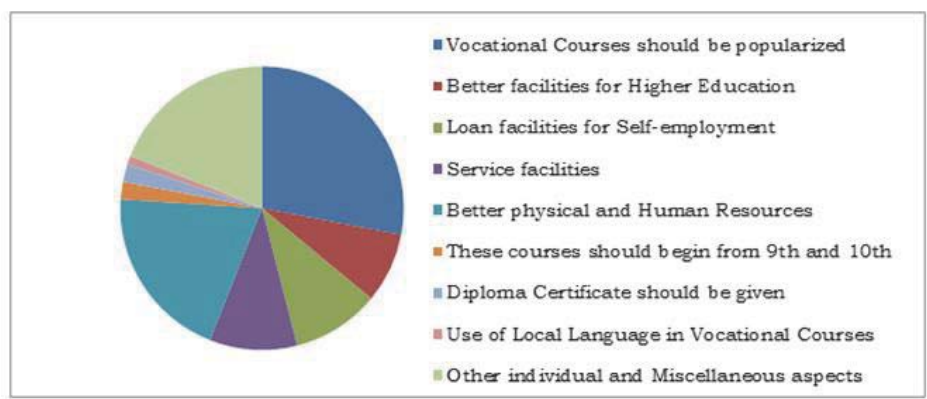

$28 \%$ students clearly tell that there is a need to popularize vocational courses in the district $8 \%$ students want better facilities for higher education in these course $10 \%$ students want loan facilities for self-employment $20 \%$ students want better physical as well as human resources for vocational courses, $10 \%$ students want service facilities after the course, 
$2 \%$ want to begin vocational courses from $9^{\text {th }}$ and $10^{\text {th }}$ classes $2 \%$ students want Diploma Certificate for such courses $1 \%$ students want the use of local language in Vocational Courses and $19 \%$ students say their views on individual and miscellaneous aspects.

\subsection{Suggestions from the Principals}

The data collected from the ten principals through interview schedules clearly indicates that in most schools the posting of teaching staff in vocational courses have not been done according to the sanctioned posts. All the ten principals are hopeful about the successful implementation of vocational programmes in Bhopal districts. Most of them are of the view better future for the students six principals are of the opinion that there should be separate building for vocational courses four principles are of the opinion that it can be accommodated the same building. All the ten principals think that the availability of the teaching staff and laboratory equipment can help us in producing better results in the field of vocational education in Bhopal district.

\subsection{Observation of Physical Facilities in Vocational Higher Secondary Schools Bhopal District}

Table 11. Availability of Physical Facilities

\begin{tabular}{|c|l|c|c|c|}
\hline S,No & Nature of Facilities & Better Position & Satisfactory & Not Satisfactory \\
\hline 1. & Building facilities & $70 \%$ & $20 \%$ & $10 \%$ \\
\hline 2. & $\begin{array}{l}\text { Laboratory and other } \\
\text { Teaching materials }\end{array}$ & $60 \%$ & $20 \%$ & $20 \%$ \\
\hline
\end{tabular}

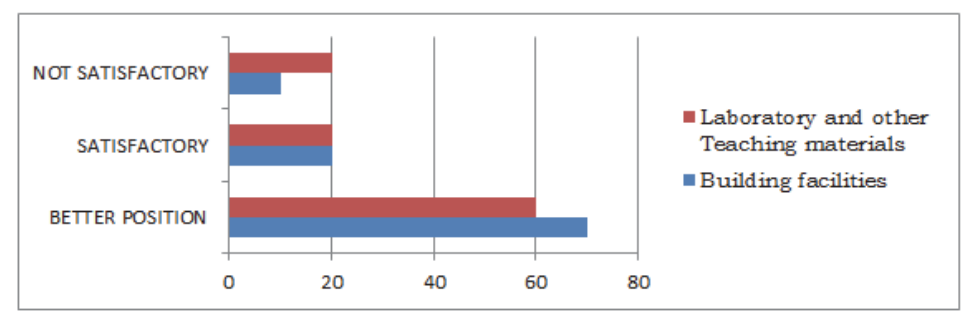

Figure 11. Availability of Physical Facilities

The above-mentioned details clearly indicate that human, as well as physical resources, are very crucial in the successful implementation of vocational education in Bhopal district. The promotion of technical knowledge has projected the need of laboratories for practical work and experiments that the students must do themselves.

\subsection{The Suggestion of the Joint Director, Public Instruction, Bhopal Division, Bhopal}

1. Vocational courses should be need based. It should be according to need of society and community.

2. The vocational courses should be changed from time to time according to the need.

3. The arrangement of facilities in on-the-job training and Industry linkage should be done.

4. The Vocational Institution should be activated, and students should be motivated for successful implementation of education.

5. The vocational students to be preferred in technical jobs.

\section{Conclusion}

The conclusions drawn from the present study have tremendous implications for improving the present state of vocational education in Higher Secondary Schools of Bhopal district. The following suggestions can be made in the context of present study.

1. More full-time teachers should be appointed. 
2. The teachers should be posted according to sanctioned posts.

3. There is an urgent need to introduce more vocational courses in rural areas.

4. There should be proper arrangement of laboratory equipment, tools and raw material in Vocational Higher Secondary Schools of Bhopal district. There should be an arrangement of school - industry linkages.

5. The industry will not be available in rural areas, but concept of establishing production - cum - training - cum service centres in the rural schools should be established.

6. Better library facilities should be available.

7. The qualitative improvement can be brought about by conducting well planned research on all the policy and implementation issues of vocational education.

8. The vocational education system itself has to address these issues and find solution.

9. Considering the multi-dimensional objectives of vocational education there is an urgent need to popularize it.

\section{References}

Raizada, P \& Sacheti, A. K. (1990).Quick Appraisal of the implementation of centrally sponsored scheme of vocationalisation of secondary education in Gujrat, NCERT

Vaid, D. K. \& Gupta, M.S. (1990).Quick Appraisal of the Implementation of centrally sponsored scheme of Vocationalisation of secondary education in 'GOA' NCERT .

Vaid, D. K. \& Gupta, M.S (1990). Quick Appraisal of the implementation of Secondary's sponsored scheme of Vocationalisation of secondary education in Rajasthan, NCERT.

Verma, Rity (1990).Quick appraisal of the implementation of centrally sponsored scheme of Vocationalisation of Education - Haryana, NCERT.

Dhote, A.K. (1991).On the Sport study of the implementation of Vocationalisation of Education Programme in the State of Karnataka, NCERT.

Bolina, P (1995).Vocational Education in India, Experience in the School System. Sterling Publishers Private Limited, New Delhi.

Amitava Krishna Dutta (1999) Development Political Economy: Major contemporary them in Encyclopaedia of Political Economy, (Ed), Phillip Anthony and O Hara, Vol-1, Routledge, London, pp: 202-206.

Alpha.C.Chiang (1984).Fundamental Methods of Mathematical Economics. McGraw Hill. International Editions. Singapore.

Baloge, Thomas(1969).Education and Agrarian Progress in Developing Countries, IG: Hufne, K. and Neumann, J. (eds) Economics of Education in Transition Stuttgart, Ernst Hett, PP.259 - 68

Boyd. T.F. and Lee. C. (1995).Educational Need and Economic Advancement: The Role of Vocational Education in the Republic of China, (Ed), PP. $193-210$.

Basu, Aparna (1979).The Growth of Education and Political Development in India 1989-1970. Oxford University press Delhi.

King, K. Martin, C. (2002), The Vocational School Fallacy Revisited: Education, Aspiration and work in Ghana 1959 - 2000, International Journal of Educational Development, 23,pp. $607-625$.

Lewink.K. (1991) Vocational Secondary Education: A Study of the Junior Secondary Schooling Innovation in Nigeria in: K.L.Lewin.J.S.Sturart (Eds), Educational Innovation in Developing Countries Macmillan. London.

Natrobi, Nwakoby, F.and Lewin K. (1991).Vocationalising Secondary Education: A Study of the Junior Secondary Schooling Innovation in Nigeria: K.M. Lewin J.S. Stuart (Eds) Educational Innovation in Developing Countries, London,

Ninth Five Year Plan (1997-2002). Government of India Planning Commission, New Delhi. Vol.11.p, 173.

Rajani Sharma (2004).Vcationalization of Education Facilitators and Distracters, Northern Book Centre, New Delhi.

Thimmaiah, G. and Seetharamu, A.S. (1982).Vocational Education Problems Prospects, Himalaya Publishing House, pp. 1, 8.

Tilak.J.B.G.(2002) Vocational Education and Training in Asia. The Hand Book on Educational Research in the Asia Pacific Region,ed, Academic Publishers pp;1-18.

Seetharamu. A.S.and Sudharao.K (1991). Research in Vocational and Technical Education. A Trend Report, New Delhi, NCERT, pp: 1286-1315.

Ministry of Human Resource (1997). Vocationalisation of secondary Education. Annual report UNDP, 2007, Human Development Report: Laws Alone cannot Guarantee Human Rights.

World Bank (1991).Vocational and Technical Education and Training" A world Bank Policy paper, Washington, D.C. World Bank.

Alley, L. R., \& Jansak, K. E. (200 1 b). Tools for quality assurance for the development of online learning in a workplace environment (a case study). http:// ausweb.scu.edu.au/aw02!papers!refereed!moran!paper.html.

Blum A (1996) Teaching and learning in agriculture: A guide for agricultural educators. FAO, Rome.

Fulton, K. (1997). Learning in a digital age: Insights into the issues: The skills students need for technological fluency [Online document]. Available http:// www.mff.org/pubs/ME164.pdf.

GOI (1986). National Policy on Education. New Delhi: Ministry of Human Resource Development, Department of Education.

GOI (1999). 81 Report on Value-based Education of the Department related Parliamentary Standing Committee on Human Resource Development, New Delhi: Ministry of Human Resource Development.

Gordon H.R.D. and Yocke R. (1999). Relationship between personality characteristics and observable teaching effectiveness of selected beginning career and technical education teachers. Journal of Vocational and Technical Education I6: ERIC Document 
Reproduction Service.

Huitt, W. (1995). A systems model of the teaching learning process. Valdosta, GA: College of Education, Valdosta State University.

Miller, P.F. and Coady, W.T. (1986). Vocational Ethics: toward the development of an enabling work ethic. Springfield: Illinois Department of Adult, Vocational and Technical Education. ERIC Document Reproduction Service No. ED 288062.

National Volunteer Skills Centre (2003). A guide to writing competency-based training materials. http://www.volunteeringaustralia.org! files/ R3Q9YOOQYO! Revised\% 20 Writers\%20Guide\%202.pdf.

Sheingold, K. (1990). Restructuring for learning with technology. The potential for synergy. In K. Sheingold \& M. Teacher (Eds.), Restructuring for learning with technology (pp. 9-27). New York: Center for Technology in Education.

WWW. Schooldee.com has a vast wealth of resources and statistics that represent the effect of teachers on a child's development. 